\title{
Current transport through ohmic contacts to indiume nitride with high defect density
}

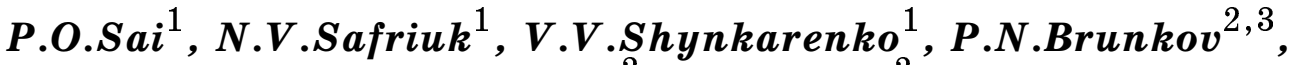 \\ V.N.Jmerik ${ }^{2}$, S.V.Ivanov \\ ${ }^{1}$ V.Lashkaryov Institute of Semiconductor Physics, National Academy of \\ Sciences of Ukraine, 03680, Keiv, Ukraine \\ ${ }^{2}$ A.Ioffe Physicotechnical Institute, Russian Academy of Sciences, 194021 \\ St.Peterburg, Russia \\ ${ }^{3}$ National Research University of Information Technologies, Mechanics \\ and Optics (ITMO), 197101 St.Petersburg, Russia
}

Received March 28, 2018

The temperature dependences of contact resistivity are measured for $\mathrm{Pd} / \mathrm{Ti} / \mathrm{Au}$ ohmic contacts toward indium nitride (with different doping level $2.0 \cdot 10^{18}$ and $8.3 \cdot 10^{18} \mathrm{~cm}^{-3}$ ) over the wide temperature range $(4.2-380 \mathrm{~K})$. The growing curves are obtained in the entire investigated temperature range for both doping level. They are explained within the mechanism of thermionic current flow through metal shunts associated with the so-called conducting dislocations. Good agreement between the theoretical and experimental dependences is obtained assuming that the flowing current is limited by total resistance of metal shunts. Moreover the effect of temperature dependence of metal resistivity on total contact resistivity was observed. The density of conducting dislocations obtained from the theory is coherent with the density of screw and edge dislocations obtained from X-ray diffraction investigation of the structure.

Keywords: ohmic contact; indium nitride, contact resistivity, current flow mechanism, rapid thermal annealing.

Получены нетипичные возрастающие температурные зависимости удельного сопротивления омических контактов $\mathrm{Pd} / \mathrm{Ti} / \mathrm{Au} \kappa$ нитриду индия с разным уровнем легирования $\left(2,0 \cdot 10^{18}\right.$ и $\left.8,3 \cdot 10^{18} \mathrm{~cm}^{-3}\right)$ в широком температурном интервале $(4,2-380 \mathrm{~K})$. Данные зависимости для разных уровней легирования обьясняются в рамках механизма токопереноса через металлические шунты, сопряженные с так называемыми проводящими дислокациями. В свою очередь металлические шунты формируются в предположении, что атомы металла проникают по дислокациям в тонкий приконтактный слой полупроводника. Хорошее согласование между теоретическими и экспериментальными зависимостями получено при учете того, что протекание тока ограничивается общим сопротивлением шунтов. Рассматривается сравнение температурных зависимостей удельного контактного сопротивления в случае осаждения на дислокациях атомов палладия или индия. При этом плотность проводящих дислокаций, рассчитанная из теории, хорошо согласовывается с плотностями винтовых и краевых дислокаций, полученных из рентгенодифрактометрических исследований структуры.

Струмоперенесення в омічних контактах до InN з високою густиною структурних дефектів. П.О.Сай, Н.В.Сафрюк, В.В.Шинкаренко, П.Н.Брунков, В.Н.Жћмерик, С.В.Іванов

Отримано нетипові зростаючі температурні залежності питомого опору омічних контактів $\mathrm{Pd} / \mathrm{Ti} / \mathrm{Au}$ до нітриду індію з різним рівнем легування $\left(2,0 \cdot 10^{18}\right.$ та $\left.8,3 \cdot 10^{18} \mathrm{~cm}^{-3}\right)$ у широкому інтервалі температур $(4,2-380 \kappa)$. Дані залежності для різних рівнів легу- 
вання пояснюються у рамках механізму струмоперенесення через металеві шунти, спряжені з так званими провідними дислокаціями. В свою чергу металеві шунти формуються у припущенні, що атоми металу проникають вздовж дислокацій у тонкий приконтактний шар напівпровідника. Хорошу узгодженість між теоретичними та експериментальними залежностями отримано при врахуванні того, що протікання струму обмежується загальним опором шунтів. Розглядається порівняння температурних залежностей питомого контактного опору у випадках осадження на дислокаціях атомів паладію або індію. При цьому густина провідних дислокацій, розрахована з теорії, добре узгоджується з густинами гвинтових і крайових дислокацій, отриманих з рентгенодифрактометричних досліджень структури.

\section{Introduction}

Indium nitride is one of the most intensely studied semiconductors among $\mathrm{A}^{3} \mathrm{~N}$ group due to the appearance of more quality material in the last years. Currently InN films are grown by Metalorganic Vapour Phase Epitaxy (MOVPE) or Plasma-Activated Molecular Beam Epitaxy (PAMBE). This semiconductor is prospective for the development of high-speed devices, due to a set of following benefits [1]: low value of electron relative effective mass $(0.04)$, the highest electron saturation velocity $\left(3.4 \cdot 10^{7} \mathrm{~cm} / \mathrm{s}\right)$ and mobility $\left(3200 \mathrm{~cm}^{2} / \mathrm{V} \cdot \mathrm{s}\right)$ among semiconductors of $\mathrm{A}^{3} \mathrm{~N}$ group.

This work was supported by the Ukranian goverment program III-41-17 (3/33).

According to the [2], one of the key problems is a creation of reliable ohmic contact to InN as an integral part of any semiconductor devices. This is due to the fact that the InN films are grown as heterostructures onto different substrate ( $\mathrm{GaN}, \mathrm{Al}_{2} \mathrm{O}_{3}, \mathrm{GaAs}$, Si etc.). Therefore, relaxation of internal mechanical stresses caused by significant mismatch of the lattice parameters and thermal expansion coefficients of the InN films and substrate generates high structural defect density. In its turn structural defects effect on the mechanism of current flow through metal-semiconductor interface. Investigation of such mechanism in case of metal-InN is the main aim of present work. It is commonly known that for solving this problem the measuring temperature dependences of contact resistivity $\left(\rho_{\mathrm{c}}(T)\right)$ is required.

There are only two groups of researchers [3-5] who studied the properties of such ohmic contacts to $n-\operatorname{lnN}$ in the $223-398 \mathrm{~K}$ temperature range [3,4] and in the $4.2-400 \mathrm{~K}$ temperature range [5]. They observed growing temperature dependences of resistance in ohmic contacts to heavily doped $n-\ln N$ with doping level over $10^{20} \mathrm{~cm}^{-3}$. In Reference [5] firstly a nanosized wire was made of heavily doped $n$-InN, then temperature dependences of the total resistance of nanowire and two identical contacts were measured. It is important to emphasize that the contact resistivity wasn't determined separately in that case.

\section{Experimental}

In order to achieve the objectives the ohmic contacts were formed by the sequential vacuum deposition of $\mathrm{Pd}(30 \mathrm{~nm}) / \mathrm{Ti}(50 \mathrm{~nm}) / \mathrm{Au}(100 \mathrm{~nm})$ onto the InN epitaxial films heated to $350^{\circ} \mathrm{C}$. Two kinds of structures with different depth of InN layer (sample A - 0.6 and sample B - 2.5 $\mu \mathrm{m})$ was grown on $\operatorname{GaN}(0.9 \mu \mathrm{m})$ buffer layer preliminarily formed on an $\mathrm{Al}_{2} \mathrm{O}_{3}$ by PAMBE. The free electron density in the $n$-InN films was $2.0 \cdot 10^{18}$ and $8.3 \cdot 10^{18} \mathrm{~cm}^{-3}$, respectively for $\mathrm{A}$ and $\mathrm{B}$ samples. Growing was monitored by reflected high-energy electron diffraction and laser refraction.

In the finally step of sample preparing the contact patterns were fabricated by the photolithography method with following metal etching and wafer cutting. In case of B sample, Rapid Thermal Annealing (RTA) was used at temperatures in the range $350-400^{\circ} \mathrm{C}$ with 2 min duration for improving metalsemiconductor contacts. No subsequent treatment of A sample was conducted. The contact resistivity was measured on planar test structures by the Transmission Line Method (TLM) before and after RTA. Measurements of $\rho_{c}(T)$ were performed for obtained structures in the $4.2-300 \mathrm{~K}$ and 100 - $380 \mathrm{~K}$ ranges for $\mathrm{A}$ and $\mathrm{B}$ samples, respectively.

Structural parameters of semiconductor epitaxial films were determined by using a High-Resolution X-Ray Diffraction (HRXRD). Both the symmetric and asymmetric reflections of InN and $\mathrm{GaN}$ were analyzed. Dislocation densities (screw NS and edge NE), lateral $\left(L_{\|}\right)$and vertical $\left(L_{\perp}\right)$ correlation length were analyzed by Williamson-Hall plots. Also the microstrain $\left(\varepsilon_{\perp}\right)$ was measured in the perpendicular plane to the growth direction from the experimentally obtained lattice parameters $(c)$. Results of HRXRD investigation are shown in Table. 
Table. Comparing of structural parameters of samples

\begin{tabular}{||c|c|c|c||}
\hline \multirow{2}{*}{$\begin{array}{c}\text { Structural parameters } \\
\text { of investigated samples }\end{array}$} & \multicolumn{2}{|c|}{ Number of sample and treatment } \\
\cline { 2 - 4 } & A (no treatment) & B (no treatment) & B (RTA 400 C) \\
\hline Lattice parameter c, nm & 0.57102 & 0.57054 & 0.57069 \\
Vertical correlation length L, nm & 670 & 557 & 9388 \\
Lateral correlation length L, nm & 230 & 481 & 546 \\
Microstrain $\varepsilon_{\perp} \cdot 10^{-4}, \mathrm{WH}$ & 4.58 & 2.11 & 0.94 \\
Screw dislocation density $N_{S} \cdot 10^{8}, \mathrm{~cm}^{-2}$ & 2.30 & 2.77 & 2.91 \\
Edge dislocation density $N_{\varepsilon} \cdot 10^{9}, \mathrm{~cm}^{-2}$ & 34.70 & 5.35 & 8.90 \\
\hline
\end{tabular}
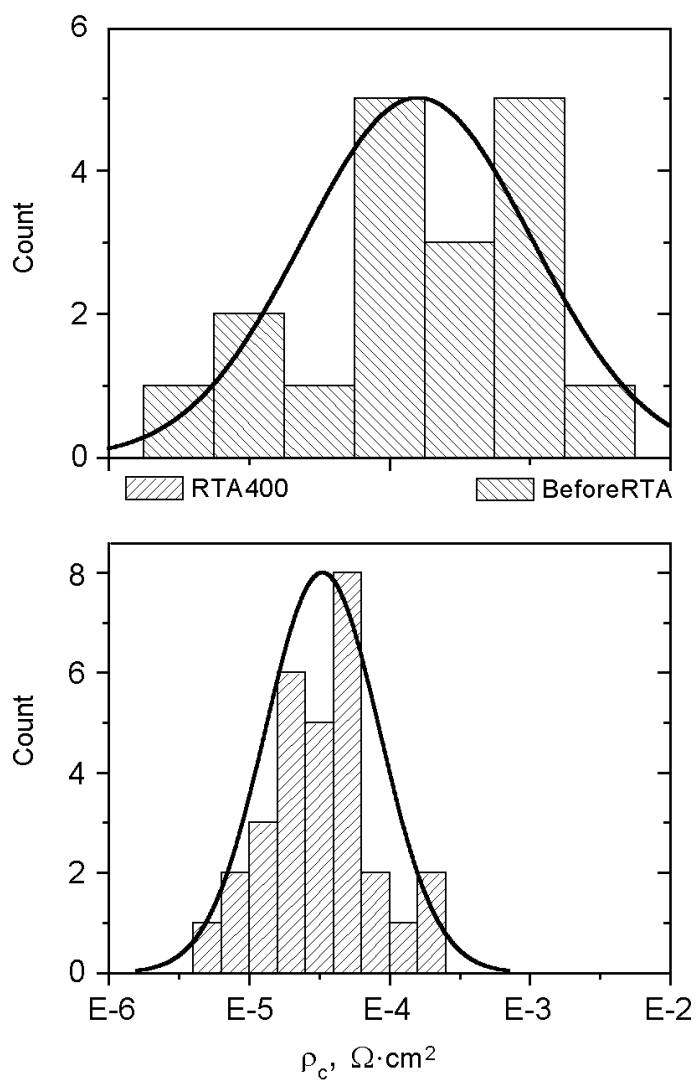

Fig. 1. Histograms of $\rho_{c}$ distribution in case of B sample: before (top) and after (bottom) RTA $400^{\circ} \mathrm{C}$.

\section{Results and discussion}

The ohmic contacts were formed to InN/GaN/Al $\mathrm{O}_{3}$ semiconductor heterostructures with high structural defect density. As known, dislocation is the dominant structural defect in $\mathrm{A}^{3} \mathrm{~N}$ semiconductors films. It was particularly confirmed by HRXRD investigation (Tabl.). The screw dislocation density of both sample types is approximately equal and slightly increases after RTA $400^{\circ} \mathrm{C}$ (for B sample). In contrast to that, the density of edge dislocation is significantly higher in

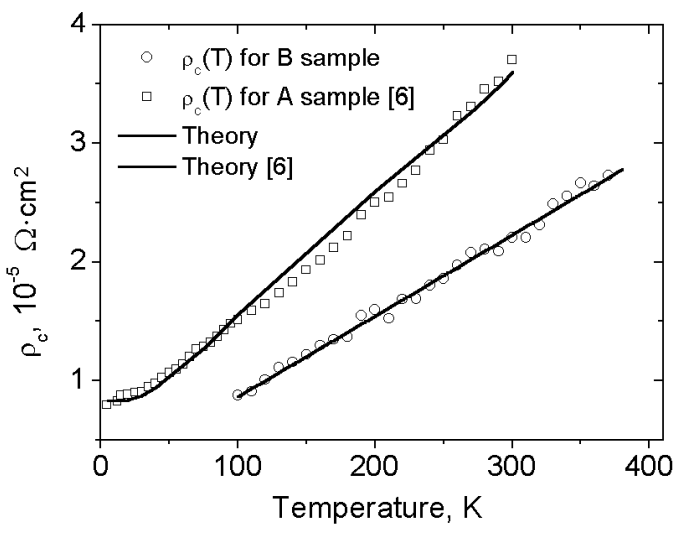

Fig. 2. Temperature dependences of contact resistivity $\rho_{c}(T)$ : dots -experimental data, line - theory.

case of A sample. As will be proved below such high dislocation density effects on the mechanism of current flow through metalsemiconductor interface and complicates task of understanding it.

Obtained from TLM measurement value of contact resistivity is $(7.61 \pm 3.96) \mathrm{p} 10^{-6}$ and $(1.58 \pm 0.56) \cdot 10^{-4} \Omega \cdot \mathrm{cm}^{2}$ for $\mathrm{A}$ and $\mathrm{B}$ samples respectively. Higher value of $\rho_{c}$ of $B$ sample was reduced to (3.31 \pm $0.49) \cdot 10^{-5} \Omega \cdot \mathrm{cm}^{2}$ after RTA $400^{\circ} \mathrm{C}$. Significantly that the width of $\rho_{c}$ spread greatly reduces after treatment as shown on the histograms of appropriate distribution (Fig. 1). According to the review [2], we obtained low $\rho c$ values that are consistent with worldwide results.

As for $\rho_{c}(T)$ dependence, we obtained similar curve in case of $B$ sample as for $A$ sample in [6] (Fig. 2). Its behavior differs considerably from curves typical for ohmic Schottky contacts with classical current flow mechanisms. There are the tunneling ( $\rho_{c}$ does not depends on temperature), the thermo-field and thermo-electron emission ( $\rho_{c}$ decreases with temperature). In our 
case, the contact resistivity grows with temperature for both sample types over the whole temperature range measured.

When performing theoretical modeling of the experimental $\rho_{c}(T)$ dependence we supposed that current flows through metal shunts associated with the so-called conducting dislocations.

To calculate contact resistivity $\rho_{t e}$ (for a contact of unit area) that is determined by supply of electrons from semiconductor to shunt ends, we apply the expressions from [6] that are true for a degenerate semiconductor:

$$
=\frac{\rho_{t e}=}{q \pi N_{D 1} L_{D}^{2} A\left(m / m_{0}\right) T} \frac{1}{\ln \left[1+\exp \left(z+y_{c 0}\right)\right]} \text {. }
$$

Here $k$ is the Boltzmann constant, $q$ is elementary charge, $N_{D 1}$ is effective density of conducting dislocations, $L_{D}$ is Debye shielding length, $A$ is Richardson constant, $m$ is effective electron mass, $m_{0}$ is free electron mass, $y_{c 0}$ is non-dimensional (normalized to $k T$ ) contact potential.

Taking into account, that not the whole area is involved in process of current flow and the resistance of all metal shunts $\left(\rho_{s h}\right)$ is connected in series with $\rho_{t e}$, the total resistivity of ohmic contact in a semiconductor with high dislocation density is

$$
\rho_{c}=\rho_{t w}+\rho_{s h} \text {. }
$$

Distinguish feature of current transport in our case is existence of potential wells rather than a potential barrier at the shunt end. It is result of following suggestion: both the edge effect (which leads to a considerable increase of the electric field strength) and the effect of the mirror image forces lead to a considerable reduction of the barrier height near a shunt. Thus, we consider non barrier mechanism of current flow thought metal-semiconductor interface.

In contrast to modeling $\rho_{c}(T)$ for A sample in [6] where we suggested current flow through palladium shunts, there are indium shunts in case of B sample. Auger profiling and investigation of surface morphology confirmed that surface of semiconductors films of B sample was enriched in indium before metal deposition. In addition the temperature dependence of palladium metal shunts, behaves in the following way [6]: at $T=0 \mathrm{~K}$, resistance of a normal metal is equal to the residual resistance. As temperature grows, the resistance increases as T5 because of electron scattering by phonons. Then a transition region with growth $\mathrm{Tn}$ is realized, with $\mathrm{n}$ decreasing rapidly. And, at last, at $T \geq T_{D}\left(T_{D}=274 \mathrm{~K}\right.$ is the Debye temperature of palladium), $\mathrm{n}=1$, i.e., metal resistance grows linearly with temperature. Thus slow growth of $\rho_{c}(T)$ for A sample at low temperature we connected with effect of palladium $\rho_{s h}(T)$. As for A sample, the Debye temperature of indium is essential lower $(129 \mathrm{~K})$ and we observe only linear increasing of total contact resistivity over whole measured temperature range $(100-380 \mathrm{~K})$.

Other essential result lies in the fact that obtained from theory densities of conduction dislocation are $5.0 \cdot 10^{9}$ and $8.8 \cdot 10^{9} \mathrm{~cm}^{-2}$ for $\mathrm{A}$ and $\mathrm{B}$ sample, respectively. These values well agree with densities of screw and edge dislocation (Table).

\section{Conclusion}

Low resistivity $\mathrm{Au} / \mathrm{Ti} / \mathrm{Pd}$ ohmic contacts were formed to indium nitride thin films with high defect density without any thermal annealing. Ability of using Rapid Thermal Annealing was also demonstrated for reduction both value of contact resistivity and its spread.

The thermionic current flow through metal shunts associated with the conducting dislocations was confirmed in case of ohmic contacts to $\operatorname{InN}$. Good agreement between the theoretical and experimental dependences of contact resistivity was obtained over wide temperature range $(4.2-380 \mathrm{~K})$. In addition, density of conduction dislocation obtained from theoretical measurement is close to densities of screw and edge dislocation determined by High-Resolution x-ray Diffraction.

\section{References}

1. Z. C. Feng, III-nitride Semiconductor Materials, Imperial College Press, Singapore, p. 442, (2006).

2. P O. Say, Tekhnologiya $i$ Konstruirovanie $v$ Elektronnoi Apparature, 4-5, 3, (2016).

3. F. Ren, C. R. Abernathy, S. J. Pearton, P. W. Wisk, Appl. Phys. Lett, 64, 1508, (1993).

4. F. Ren, C. B. Vartuli, S. A. Pear, et.al.,Vac. Sci. Technol A, 15, 802, (1997).

5. C.-Y. Chan, G.C. Chi, W.M. Wang, L.C. Chen, et.al., Appl. Phys. Lett., 87, 093112-1 093112-3, 2005.

6. A. V. Sachenko, A. E. Belyaev, N. S. Boltovets, et.al., Semiconductors, 49, 461, (2015). 